\title{
THE INFLUENCE OF APPLYING ACROSTIC TECHNIQUE ON THE STUDENTS' ACHIEVEMENT IN LEARNING ENGLISH
}

\author{
Darmawati \\ \{darmawati@gmail.com\} \\ Faculty of Teacher's Training and Education University of Muhammadiyah \\ Sumatera Utara. Medan, Indonesia
}

\begin{abstract}
The objective of this study was to know the influence of applying the acrostic technique on the students' achievement in learning English. The study applied the experimental method. The population of this research was the students the second semester in FKIP UMSU which consisted of 175 students, the researcher took $50 \%$ and there were 88 students as the sample. The samples were divided into two groups, the first group was the experimental group by using the acrostic technique that consisted of 44 students and the second group was control group by using conventional method that consisted of 44 students. The data were acquired by administrating a writing test especially the description of people. The data collected were analyzed by performing experimental techniques. After analyzing, the result of the students' using the acrostic technique was higher than those being taught by using a conventional method. The result of the data was tobserve $>$ table or $2.87>2.03$ for $5 \%$. It means that the alternative hypothesis is accepted and the null hypothesis is rejected. From determining the percentage of the influence of $\mathrm{x}$ variable toward $\mathrm{y}$ variable in writing descriptive text was $80 \%$ and $20 \%$ was influenced by another factor.
\end{abstract}

Key words : Acrostic Technique, Learning English

\section{INTRODUCTION}

The study English is the most difficult subject, especially learning to write in English. The students must use grammar and vocabulary, so that the students do not like to study English, especially in writing. And many students of the sixth semester at Muhammadiyah University get troubles in writing and some of them are even frustrated when they have to do it. Sembiring (1981: 1) states that writing is the most difficult to study. It will be easier to study after the students have a written, they must study hard and master the grammar. For writing paragraphs, the students can express their ideas, feelings, and purposes easily. Harmer (2004:3) said as one of the four skills of language, writing has always formed part of the syllabus in the teaching of English; there has been a growing interest in it and necessity for English for International technology and communication. Applying the acrostic technique is the most important thing for the sixth-semester students 2018-2019 Academic Year in the 
teaching- learning process at FKIP UMSU. By applying the acrostic technique is valuable for students' achievement in the teaching-learning process. Hence looking at the essay test to write a paragraph the students can express the ideas, feeling and purposes easily. Besides that, an acrostic is one technique that can measure students' achievement especially in writing and help them to understand the materials easily. And they can feel enjoyable to express their ideas. And applying the acrostic technique can encourage the students' interest and ability in writing, also makes the students easier in developing their ideas in writing.

Writing; Tiwari, (2005: 120) states that writing is a complex process that allows writers to explore thoughts and ideas, and make them visible and concrete. It is the way for people to convey their thoughts in written forms. Writing also enables people to express their feelings and observations to others. Writing helps us to remember, to observe, to think and to communicate. Further, Tiwari states that a well-written piece can be described as incorporating elements of writing in such a way that a reader can experience the writer's intended meaning, understand the writer's promise, accept or reject the writer's point of view. An effective writing has certain characteristics, such as 1) Focused on the topic and does not contain extraneous or loosely related information; 2) Has an organizational pattern that enables the reader to follow the flow of ideas because it contains a beginning, middle, and end and uses transitional devices; 3) Contains supporting ideas that are developed through the use of details, examples, mature word choice; and 4) Follows the conventions of standard written English and has variation in sentence structure. According to Carroll et al (2001: 15) In producing a writing piece, there is a process involved. Process is the stage where the researcher goes through to produce a writing matter. Carroll et al. (2001: 15) elaborate the stages of writing process as follows: 1) Prewriting: freely exploring topics, choosing your topic, and beginning to gather and organize details before you write; 2) Drafting: getting your ideas down on paper in roughly the format you intend; 3) Revising: correcting any major errors and improving the writing's form and content;4) Editing and proofreading: Polishing the writing; fixing errors in grammar, spelling, and mechanics; 5) Publishing and presenting: sharing your writing. The students as the writer must learn about the purpose of various writing. The purpose of writing is discussed in the field of genre. Oxford Advanced Learner's Dictionary (1995) defines the term of genre as a particular style or type, especially of works of art or literature. Genres are classified according to their social purpose and identified according to the stages they move through to attain their purposes. Garrot and Wignell (1994:190) explain that different genre deploys the resources for meaning-making through grammar in different ways. These genres arose in social interactions to fulfill human's social purposes. There are different genres of writing: Spoof, Recount, Report, Analytical exposition, Hortatory exposition, New item, Anecdote, Narrative, Procedure, Explanation, Discussion, Review, and Description. Descriptive Text; According to Wyrick (2004: 317) Description is a word-picture of persons, places, objects, and emotions, using a careful selection of details to make an impression on the reader. Pardiyono (2006: 165) stated that descriptive is one of the writing types, besides of narrative, recount, information report, discussion, explanation, exposition, procedure, anecdote, advertisement-persuasive exposition. Descriptive text is a text that description of an object, both living things and dead things, including human and animals. Descriptive text focus on the description of parts, characteristics, specialties, qualities, or quantities, by using adjectives or attributes.

Acrostic Technique; According to Sheakoski (2007: 4), acrostic technique is a technique that uses acrostic to make writing a descriptive paragraph easier to do. This technique is included in prewriting and done after the writer of the descriptive paragraph decides the topic 
of his paragraph. Acrostics can be used at the beginning of a school year as a way for students to introduce themselves to each other or a pre-writing activity for descriptive paragraphs. Carbery (1999: 144) states that acrostic is an ideal way of practicing adjectives and as an introduction to descriptive writing. Glandon (2000: 145) mentions that acrostic is a distinctive, creative way of reporting research notes because it describes the topic and use the letters of the topic to begin each line. The acrostic is used in the pre-writing process for gathering details to create a descriptive paragraph. The details are gained by writing down the characteristics of the title following the pattern of acrostic. The Procedure of Acrostic Technique; According to Sheakoski (2007: 4), there are two main steps in the procedure of the acrostic technique. After the topic is decided, the steps are: the first step is creating the acrostic, and the second step is elaborating the details in the acrostic into a descriptive paragraph. In creating the acrostic, to make it easier for the students, the teacher should work together with the class to brainstorm the descriptive words or details that describe the topic. The students can also consult their dictionary for getting a rich description. The description 
can be a single word, phrase or even sentence. After that, brainstorm a list of 'bridge words' (prepositions, conjunctions, and other words) that can be used when students are writing their acrostic.

\section{METHOD}

The population of this research was the 2018/2019 second semester students of English Department of FKIP UMSU. There were five classes consist of 175 students. For the sample of this research, 88 students were taken out as the sample of this research. It was called as representative according to Arikunto (2006: 134) who stated that if the number of population is less than 100, it is better to take all of population, then if the number of the population is more than 100 the sample can take $10-15 \%, 20-25 \%$ or up. Based on the quotation above, the researcher took $50 \%$ for taking the sample. This research design was an experimental design, which consists of pre-test and post-test to know the influence of applying acrostic techniques on students' writing skills. A pre-test was the test that was given before the treatment process has begun. The test was aimed to find out the student's writing skills of both groups. In conducting the experimental research the sample was divided into two groups. Both experimental and control groups were given the same test, they were asked to write a descriptive text based on the given situation. Hughes (2003: 104) said that collecting data in this research was an essay test. The result of the test was compared to find out the influence of using the acrostic technique in writing. The students were asked to write based on the topic given. The topic is 'The special person in my life'.

\section{FINDING AND DISSUSSION}

The results of the research show that students' achievement taught by using the acrostic technique got a higher score than the students' achievement which taught without acrostic technique in writing descriptive. The students' achievement taught by using the acrostic technique got more interest in solving writing mastering than the students' achievement which taught by using conventional technique in writing descriptive. From the score that the students got it showed that using the acrostic technique in writing descriptive text is effective to be used. Another researcher tell any different skill by using learning write the poetry strategy with acrostic technique and the groups which not following study by using learning write the poetry strategy with acrostic technique that it has effective learning write the poetry strategy with acrostic technique than the groups which not following study by using learning wrote the poetry strategy with acrostic technique. According to Maryam Jamilah showed that using the acrostic technique was more effective than using image media. Based on the values obtained, in SPSS 22 the t-test calculation shows 0,000. She said that learning to write poetry by using an acrostic technique can improve students' ability to write poetry and increase students' creativity in learning to write poetry. As for researchers' suggestions, learning using this acrostic technique can be used as learning techniques used by teachers in the learning process. This technique also facilitates students to remember the material being taught by the teacher thus students can develop their creativity as much as possible. Other studies also explain the acrostic technique could be given a positive effect on poetry writing learning outcome and achievement motivation of fifth-grade students in Elementary School. Based on Desak Putu's argument acrostic learning developed involving students in a way active in the learning process this starting from planning, implementation until the assessment process. Learning acrostic is carried out by seeing student ability, so that allows students to be 
motivated to continuous and full learning with charge linkages with a real problem. Acrostic learning focus attention on observation and assessment of symptoms or daily events, soallows students to understand a learning phenomenon of all side, which in turn will later make students more active and wise in responding or facing events which exist.

\section{CONCLUSION AND SUGGESTION}

From this research, it is found that the using of acrostic technique can cause a positive influence on students' writing descriptive text, which is proved from the result of the test tobserve $>$ table or $2.87>2.03$. The students who are taught by using the acrostic technique get better achievement than those who are taught by using conventional technique. Teaching acrostic technique has a more significant influence than teaching by using the conventional technique on students' writing achievement for example, the students who are taught by using acrostic technique are more active and brave to write and shows their ideas or opinion; while the students who are taught by using conventional technique still must focus their writing through memorizing vocabulary. Therefore, they cannot get some opportunities to develop their ideas or opinions. Therefore, the second-semester students of the English Department of FKIP UMSU 2018/2019 Academic Year have a more significant influence in writing descriptive text by using the acrostic technique. And suggested for teachers and students: 1) English teachers to apply acrostic techniques on the students' achievement in writing descriptive text because it helps the students to gather details through a creative draft and make the writing process easier to do. 2) It is suggested for English teachers to guide their students in writing descriptive text by using the acrostic technique because this technique provides a fun way to create a descriptive text, so the writing process will not be boring and hard. The students should be trained to write in English as a part of the skills to further develop their ability in writing descriptive text.

\section{Acknowledgement}

First, in the name of Allah the most Almighty, the most merciful, all of praise to Allah the most almighty who already gave her health and mercy so that the author was able to finish this article. Second, peace be upon to the noble prophet Muhammad, as the figure of good civilization, intellectual, braveness, knowledge lover and who had brought human beings from the darkness into the brightness. And the last, the author would like to say thank you to reviewers who have provided criticism and guidance this article, so that in this article can be completed well and optimally to make a better one. The author is very aware that this article still has many shortcomings.

\section{REFERENCES}

Arikunto, Suharsimi. 2006. Procedure Penelitian : Suatu Pendekatan Praktik.Jakarta: Rineka.

Harmer, Jeremy. 2001. The Practice of English language Teaching. $3^{\text {rd }}$ Edition.Harlow: Longman.

Hughes, Arthur. 2003. Testing for Language Teachers $2^{\text {nd }}$ Edition. Cambridge:Cambridge University Press.

Gerrot, L and Wignell, P. 1994. Making Sense on Functional Grammar. Sydney: Gerd Stabler. 
Pardiyono, 2006. 12 Writing Clues for Better Writing Competence. Yogyakarta:Andi Sembiring. 1981. Good Foundation of Grammar. Jakarta: Bina Aksara.

Sheakoski, Megan. 2007. A Poetry Guide for Elementary School Students. Availableat: http: // curriculalessons. suitelol. com/ article. cfm/ writing poems with kids (accessed on January, $1^{\text {st }}, 2012$ ). 
Tiwari, Deepak. 2005. Encyclopedia of Modern Methods of Teaching. Volume- 7.

New Delhi. Crescent publishing Corporation.

Wyrick, Jean. 2001. Steps to Writing Well-A consist Guide to Composition. $6^{\text {th }}$ Edition.

Colorado State University: Harcourt Brace College Publishers

Maryam, Jamilah.2019.Learning to Write Poetry by Using an Acrostic Technique on Class X

Students in SMK. Volume 2 Number 1, January 2019 E - ISSN 2621-0169

Putu, Desak Rohika and A A Istri Ngurah Marheni.2014. The Effect of Poetry Writing Using Acrostic Technique To Fifth Grade Elemantary Student's Poetry Writing Learning Outcome And Achievement Motivation in Elementary School District 6 Sub-District Gianyar. eJournal Program Pascasarjana Universitas Pendidikan Ganesha Program Studi Pendidikan Dasar (Volume 4 Tahun 2014)

https://journal.ikipsiliwangi.ac.id/index.php/jler/article/view/2729/pdf 